DOI: https://doi.org/10.47405/mjssh.v6i8.948

\begin{tabular}{|c|c|}
\hline s & Malaysian Journal of Social Sciences and Humanities (MJSSH) \\
\hline Malaysian Journal of & Volume 6, Issue 8, August 2021 \\
\hline $\begin{array}{l}\text { Humanitits } \\
\text { (MJ. IsH) }\end{array}$ & e-ISSN : 2504-8562 \\
\hline & $\begin{array}{l}\text { Journal home page: } \\
\text { www.msocialsciences.com }\end{array}$ \\
\hline
\end{tabular}

\title{
Burnout: Hubungannya dengan Tekanan Kerja dalam kalangan Guru-Guru Pendidikan Jasmani Sekolah Menengah di Daerah Kota Kinabalu, Sabah
}

\author{
Lauretta Eva Adrian', Norlena bt Salamudin ${ }^{1}$, Norasmah bt Othman ${ }^{1}$ \\ ${ }^{1}$ Fakulti Pendidikan, Universiti Kebangsaan Malaysia (UKM) \\ Correspondence: Lauretta Eva Adrian (P101186@siswa.ukm.edu.my)
}

\begin{abstract}
Abstrak
Tekanan kerja yang melampau perlu ditangani dengan cepat bagi mengelakkan berlakunya burnout dalam kalangan guru-guru di sekolah. Tujuan kajian ini dijalankan adalah untuk mengenal pasti tahap tekanan kerja dengan tahap burnout guru-guru Pendidikan Jasmani di Daerah Kota Kinabalu. Seterusnya kajian ini juga dijalankan bagi mengenal pasti hubungan antara tekanan kerja dengan burnout guru-guru Pendidikan Jasmani di Daerah Kota Kinabalu. Kajian ini menggunakan kajian tinjauan yang melibatkan seramai 136 orang guru Pendidikan Jasmani. Bagi memenuhi kehendak kajian ini, satu tinjauan menggunakan soal selidik diedarkan instrumen kajian digunakan Teacher Stress Inventory dan Maslach Burnout Inventory (MBI). Data dianalisis menggunakan perisian Statistical Packages for Social Science (SPSS) versi 26.0. Hasil kajian menunjukkan tahap tekanan kerja berada pada tahap sederhana rendah. Tahap tekanan kerja bagi ketiga-tiga aspek iaitu kerenah pelajar, beban tugas, dan penghargaan berada pada tahap sederhana rendah manakala aspek kekangan masa mencatatkan tahap sederhana tinggi. Tahap burnout guru bagi sub skala keletihan emosi berada pada tahap rendah manakala sederhana tinggi bagi sub skala depersonalisasi dan lemah bagi sub skala pencapaian peribadi. Hasil kajian mendapati tidak terdapat hubungan yang signifikan antara tekanan dengan sub skala burnout bagi keletihan emosi, depersonalisasi dan pencapaian peribadi.
\end{abstract}

Kata kunci: Burnout, tekanan guru, keletihan emosi, pencapaian peribadi, depersonalisasi

\section{Burnout: The Relationship with Work Stress Among Secondary School Physical Education Teachers in Kota Kinabalu District, Sabah}

\begin{abstract}
Extreme work stress needs to be addressed quickly to prevent burnout among teachers in schools. The purpose of this study was to identify the level of work stress with the level of burnout of Physical Education teachers in the District of Kota Kinabalu. This study was also conducted to examine the relationship between work stress and burnout of Physical Education teachers in Kota Kinabalu District. This study uses a survey study involving a total of 136 Physical Education teachers. To meet the requirements of this study, a survey using a questionnaire distributed research instruments used Teacher Stress Inventory and Maslach Burnout Inventory (MBI). Data were examined using the latest version of Statistical Packages for Social Science (SPSS) version 26.0 to conduct statistical analyses. The study's findings found that the level of work stress is at a moderately low level. The level of work stress for all three aspects, namely student frustration, workload, and appreciation, was at a moderately low level, while the aspect of time constraints recorded a moderately high level. Teacher burnout levels for the emotional exhaustion subscale were low while moderately high for the depersonalization
\end{abstract}


subscale and high for the personal achievement subscale. The findings of the study found that there is no significant relationship between stress and burnout subscale for emotional exhaustion and depersonalization and personal achievement.

Keywords: teachers stress, burnout, emotional exhaustion, personal achievement, depersonalization

\section{Pengenalan}

Guru mempunyai tanggungjawab besar dalam mempersiapkan anak muda untuk menjalani kehidupan yang berjaya dan produktif. Ketika ini, profesion perguruan merupakan pekerjaan yang paling mencabar. Guru terdedah dengan sindrom tekanan dan burnout disebabkan oleh bebanan tugas serta masa kerja berterusan sama ada di sekolah mahupun di rumah (Mohd Effendi, 2021). Profesion perguruan merupakan bidang terpenting dalam mendidik, mengajar dan membentuk sesebuah tamadun bangsa serta membimbing seorang manusia yang berguna dalam menghadapi kehidupan selari dengan Falsafah Pendidikan Kebangsaan (Kementerian Pendidikan Malaysia, 2021).

Menurut Waterford (2019), hasil kajian di tujuh sekolah luar bandar di tenggara Ohio mengatakan 25 peratus daripada guru menganggap pekerjaan mereka sangat terbeban dan seterusnya memberi tekanan kepada mereka. Sementara 46 peratus lagi melaporkan bahawa mereka sentiasa merasa tertekan setiap hari sepanjang tahun persekolahan. Ini menjadikan profesion perguruan sebagai salah satu pekerjaan yang memberi tekanan tinggi di Amerika Syarikat (Waterford, 2019). Berdasarkan kajian luar negara, bagi membentuk minda seorang guru, sekolah perlu mempunyai seorang pemimpin yang mempunyai visi untuk bekerjasama dengan guru-guru agar dapat mengurangkan rasa tekanan terhadap perubahan tersebut. Perubahan dalam sistem pendidikan yang sentiasa berubah juga boleh menyebabkan guru terbeban seterusnya menyebabkan guru mengalami tekanan dalam pekerjaan (Berita Harian, 2018).

Sejak kebelakangan ini, sistem organisasi sekolah sentiasa mengalami pelbagai permasalahan dalam hubungan baik antara pemimpin dan guru-guru serta pengurusan pendidikan serta hubungan baik antara pemimpin serta guru-guru. Antaranya, ketidakhadiran guru, kelewatan guru masuk kerja, guru tidak serius dalam pengajaran, komitmen kerja guru, disiplin guru dan kemajuan sekolah (Fauziah et al., 2008). Bila diteliti semula, isu dan permasalahan tersebut berlaku kerana guru merasa mereka terbeban dengan tugas-tugas kerana seperti mengutip yuran, mengemaskinikan kehadiran pelajar dalam aplikasi pangkalan data murid, melaksanakan pentaksiran aktiviti jasmani, sukan dan kokurikulum, menyediakan laporan kemajuan pelajar, menyediakan kertas peperiksaan, membimbing pelajar bagi memajukan pelajarnya (Syed et al. 2017). Ini mengakibatkan mereka merasa burnout dan akhirnya hilang motivasi. Hal ini selari dengan hasil kajian Hoy, (2005) apabila beliau turut menyatakan perkara yang sama, dimana pentadbir sekolah dan guru-guru perlu menjalinkan hubungan baik untuk mencapai matlamat organisasi sekolah.

Dalam pada itu, salah satu sebab guru tertekan adalah kerana penerimaan elaun yang berbeza antara guru-guru dari Sabah, Sarawak dan di Semenanjung. Jumlah perbezaan elaun yang diterima oleh guru dari Sabah dan Sarawak adalah antara RM280 dan RM630, satu jumlah yang besar (Berita Harian, 2012). Melalui keratan akhbar Berita Harian (2018) ada menjelaskan bahawa guru Sabah dan Sarawak yang berkhidmat di Semenanjung selepas setahun bertukar, tidak merasai pelbagai imbuhan seperti imbuhan tetap perumahan (ITP), elaun perpindahan wilayah (EPW) dan elaun sara hidup (COLA). Hal ini menyebabkan mereka tidak bersemangat untuk mendidik pelajar-pelajar seterusnya menjejaskan prestasi akademik sekolah terbabit disebabkan tertekan dengan perbelanjaan pada masa kini semakin meningkat.

Dalam situasi ini, guru-guru perlu bijak mengawal dan merawat tekanan yang dihadapi seterusnya bagi mengelakkan burnout berlaku. Dalam hal ini, kajian ini dilaksanakan untuk mencari jalan penyelesaian kepada masalah yang dihadapi oleh guru-guru seperti yang dinyatakan di atas agar guru dapat menjalankan tanggungjawab sebagai pendidik yang baik. Tanggapan guru terhadap keadaan persekitaran sekolah juga menjadi perkaitan terhadap permasalahan burnout di kalangan guru (Grayson 
dan Alvarez, 2008). Hasil kajian Collie et al. (2012) mendapati tiada sokongan sosial, kesedaran masyarakat yang kurang dan perhubungan yang tidak baik antara pihak pentadbir dan guru-guru menjadikan ianya sebagai sumber utama kepada kemenjadian burnout guru-guru di sekolah. Dalam usaha membantu guru-guru, khasnya kepada guru-guru Pendidikan Jasmani sekolah menengah di daerah Kota Kinabalu, Sabah menangani masalah burnout dan tekanan burnout, satu kajian bagi mengkaji hubungan burnout dan tekanan yang dilalui guru-guru dijalankan agar permasalahan ini dapat diselesaikan.

Pernyataan masalah dalam kajian ini adalah untuk membincangkan permasalahan seperti yang digariskan sebagai persoalan kajian dalam penyelidikan ini. Permasalahan yang pertama, tahap tekanan guru boleh berubah kerana tekanan yang dihadapi bukan sahaja dari sekolah malah di luar sekolah juga (Effendi, 2021). Kedua, tahap burnout yang dilalui guru-guru sehingga menyebabkan ramai guru-guru mengambil keputusan untuk berpencen awal. Ketiga, adakah terdapat hubungan antara tekanan dan burnout sehingga guru-guru tidak dapat melaksanakan tanggungjawab sebagai seorang pendidik dengan baik (Jay, 2020).

\section{Tinjauan Literatur}

\section{Burnout}

Burnout menyebabkan seseorang mengalami penurunan produktiviti kerja dan kurang bertenaga, menjadikan seseorang berasa cepat letih dan malas melakukan tugas yang diber (Smith, 2020). Tanggapan guru terhadap persekitaran sekolah mempunyai hubungan terhadap berlakunya burnout dalam kalangan pendidik (Grayson \& Alvarez, 2008). Hasil kajian Collie et al. (2012) mendapati tiada sokongan sosial, kesedaran masyarakat yang kurang dan perhubungan yang tidak baik antara pihak pentadbir dan guru-guru menjadikan ianya sebagai sumber utama kepada kemenjadian burnout dalam kalangan guru-guru di sekolah. Sumber utama tekanan dan burnout di dalam kelas adalah keberkesanan diri yang rendah, atau guru yang kekurangan kepercayaan dalam diri untuk mencapai matlamat mereka (Skaalvik, 2010). Secara umumnya, burnout dibahagikan kepada tiga iaitu gejala fizikal, emosi dan tingkah laku (Zakaria, 2021). Kerjaya guru merupakan profesion yang mengalami tahap burnout tertinggi berbanding dengan pekerjaan lain (Hakanen, 2006).

Burnout terbahagi kepada tiga sub skala iaitu keletihan emosi, depersonalisasi dan pencapaian peribadi (Maslach et al. 2001). Setiap sub skala mempunyai perbezaan aspek. Keletihan emosi terjadi apabila seseorang sentiasa merasa gagal dan gelisah dalam pekerjaan. Aspek depersonalisasi adalah salah satu pemikiran yang kearah negatif terhadap orang sekelilingnya. Bagi sub skala pencapaian peribadi pula menjurus kepada seseorang yang sentiasa mengharapkan balas keatas pekerjaanya atau pembentukan sikap negatif dalam pemikirannya.

Menurut Choi (2018) mengatakan hubungan tekanan psikologi yang tinggi dengan guru boleh menjejaskan kesihatan guru, guru kerap mengambil cuti, bertukar ke tempat kerja lain dan akan menjejaskan pencapaian pengajaran guru. Kajian lepas mendapati bahawa, tingkah laku negatif dalam bilik darjah sehingga menyebabkan guru menegur dengan kadar teguran yang tinggi dan keras mengakibatkan guru mengalami keletihan emosi. Tekanan guru sering dikaitkan dengan kerenah pelajar yang menjadi salah satu penyebab utama berlakunya tekanan di tempat kerja serta permasalahan lain seperti tidak mendapat sokongan pihak organisasi sekolah, hubungan dengan ibu bapa dan kecekapan peribadi serta profesion yang rendah (Shkëmbi, 2015).

\section{Tekanan}

Tekanan kerja berasal daripada perkataan Latin "stringere" yang merujuk kepada penderitaan mental dan fizikal (Birhanu, 2018). Ia dimaksudkan sebagai beban kehidupan yang dialami oleh pekerja yang melakukan pekerjaan bukan spesifik ke atas diri mereka (Vickovic, 2019). Sebagai contoh, pekerja melakukan pekerjaan di luar bidang dan kemampuannya yang rendah menyebabkan individu tersebut tidak dapat melaksanakan pekerjaan dengan baik (Dameria, 2020). Menurut Zaid (2015) tekanan 
didefinisikan sebagai salah satu desakan atau imaginasi seseorang yang disebabkan oleh tindak balas emosi yang tidak menentu. Ianya adalah normal bagi seseorang yang bekerja dalam bidang prosesion contohnya pekerjaan guru untuk mengalami tekanan kerja. Setiap individu yang sentiasa sibuk dengan pekerjaan pasti akan mengalami tekanan kerja.

Tekanan (stress) yang tidak dibendung dari awal boleh mendatangkan kesan buruk ke atas kesihatan mental dan fizikal seseorang. Azmi (2005) menjelaskan bahawa salah satu penyebab berlakunya tekanan kerja adalah disebabkan oleh bebanan tugas, kekurangan masa kerja hubungan rakan sekerja, dan kualiti penyeliaan yang lemah. Menurut Zafir (2019) berdasarkan data dari kajian Bahagian Psikologi dan Kaunseling, Kementerian Pendidikan Malaysia (KPM) mendapati seramai 48,259 guru (4.4 peratus) mengalami stress pada tahap sederhana tinggi.

\section{Burnout dan stres}

Terdapat beberapa kajian berkenaan dengan burnout dan stres yang telah dijalankan bertujuan untuk mengenal pasti tekanan dalam kalangan guru, sebagai contoh kajian di China oleh Dai et al. (2015). Kajian Dai et al, (2015) bertujuan untuk menguji sama ada tekanan berkolerasi atau tidak dengan perasaan burnout yang dialami para guru. Hasil kajian mengatakan, tekanan pekerjaan yang melampau tidak dapat ditangani dengan segera oleh guru sehingga membuatkan guru hilang minat terhadap tugas mereka berkorelasi dengan perasaan burnout guru. Oleh itu, tekanan kerja yang melampau kebanyakannya boleh menyebabkan burnout berlaku (Zhao et al. 2014). Dengan tahap tekanan yang begitu tinggi, tidak hairanlah jika banyak guru mengalami burnout pada suatu masa sepanjang pekerjaan mereka. Punca utama tekanan dan burnout di dalam kelas adalah keberkesanan diri yang rendah, atau kurangnya kepercayaan guru terhadap diri sendiri.

Tekanan dan burnout guru-guru di bandar banyak dipengaruhi oleh permintaan pekerjaan dan sumber yang ada (Bottiani, 2020). Disebabkan permintaan pekerjaan guru ramai, pihak kerajaan tidak dapat menapis dengan betul tentang latar belakang guru baharu yang mengalami tahap kemiskinan yang tinggi, tahap pendedahan pengajaran dan pembelajaran kurang, emosi tidak stabil, dan tingkah laku pelajar mereka di dalam kelas menyebabkan guru-guru mengalami tekanan seterusnya boleh menyebabkan burnout berlaku (Bottiani, 2020).

\section{Metod Kajian}

Reka bentuk kajian menggunakan pendekatan kaedah tinjauan yang berbentuk kajian kuantitatif. Kaedah tinjauan ini dipilih kerana ia menepati objektif kajian selain data dapat diperoleh dengan cepat dan tepat walaupun kedudukan responden bertaburan. Populasi kajian ini pula adalah guru-guru Pendidikan Jasmani dan Kesihatan di Daerah Kota Kinabalu, Sabah seramai 210 orang. Daripada jumlah tersebut, seramai 136 guru telah dilibatkan dalam kajian. Pemilihan sampel ini dibuat dengan menggunakan kaedah rawak mudah bagi mengelakkan bias. Sementara penentuan saiz sampel dibuat berasaskan jadual Krejcie dan Morgan dalam Chua (2011).

Pengkaji mengedarkan borang soal selidik menggunakan kaedah atas talian. Ini kerana negara sedang bergelut dengan pandemik Covid-19 yang menyebabkan semua organisasi pendidikan ditutup. Oleh yang demikian, soal selidik diedarkan secara atas talian dengan menggunakan Google Form yang diberikan melalui email responden.

Seterusnya, kajian ini menggunakan soal selidik sebagai instrumen. Set soal selidik dibahagikan kepada tiga bahagian iaitu bahagian A: demografi responden yang mengandungi lima item seperti jantina, umur, status perkahwinan, opsyen guru, dan pengalaman mengajar. Bahagian B: bagi mengukur tekanan guru-guru, pengkaji menggunakan instrumen soal selidik Teacher Stress Inventory Boyle et al. (1995) yang telah diadaptasi oleh Mokhtar (1998). Soal selidik ini mengandungi 20 item terdiri daripada empat aspek utama iaitu karenah pelajar, bebanan tugas, kekangan masa dan penghargaan. Item soal selidik diukur menggunakan skala likert lima mata iaitu 1 (tiada tekanan), 2 (tekanan rendah), 3 (tekanan sederhana), 4 (tekanan tinggi), dan 5 (tekanan sangat tinggi). Bahagian C: 
tahap burnout diukur menggunakan instrumen soal selidik Maslach Burnout Inventory (MBI) (Maslach 1996). Soal selidik MBI yang mempunyai 22 item menggambarkan tiga dimensi utama dalam burnout iaitu kelesuan emosi, depersonalisasi dan pencapaian peribadi. Skala likert enam mata digunakan untuk item burnout guru dengan pemilihan jawapan dari 0 (Tidak pernah), 1 (beberapa kali dalam setahun), 2 (sekali dalam sebulan), 3 (beberapa kali dalam sebulan), 4 (sekali dalam seminggu), 5 (beberapa kali dalam seminggu) hingga 6 (Setiap hari). Tahap burnout guru ditentukan dengan melihat skor mata bagi ketiga-tiga dimensi. Guru tidak mengalami burnout jika skor subskala keletihan emosi dan depersonalisasi serta subskala pencapaian peribadi adalah rendah.

Kajian rintis dijalankan kepada 30 responden bagi mendapatkan nilai kesahan dan kebolehpercayaan soal selidik. Keputusan bagi nilai kesahan dan kebolehpercayaan untuk kedua-dua instrumen soal selidik ini berada pada tahap yang baik dan boleh diguna pakai dalam kajian ini. Menurut Sidek dan Jamaludin (2005), sesebuah soal selidik itu mempunyai kesahan kandungan yang tinggi apabila memperoleh $70 \%$ dan dianggap telah menguasai atau mencapai tahap pencapaian yang tinggi. Berdasarkan Jadual 1, nilai kesahan bagi Maslach Burnout Inventory (MBI) adalah 0.6 hingga 0.9 yang mana nilai tersebut sangat baik. Nilai kesahan Teacher Stress Inventory ialah 0.9. Nilai ini adalah sangat baik dan memuaskan serta boleh diterima untuk digunakan (Hair et. al, 2006). Nilai pekali Alpha Cronbach bagi Maslach Burnout Inventory (MBI) untuk sub skala keletihan emosi ialah 0.893 ( $\alpha=.893)$, sub skala depersonalisasi $0.667(\alpha=.667)$ dan sub skala pencapaian peribadi $0.938(\alpha=$ .938). Manakala, nilai pekali Alpha Cronbach bagi alat ujian Teacher Stress Inventory ialah 0.905 ( $\alpha=$ .905).

Jadual 1 : Ujian Kesahan dan Kebolehpercayaan Instrumen

\begin{tabular}{lcccc}
\hline Pemboleh ubah & Jumlah Item & $\begin{array}{c}\text { Nilai Alpha } \\
\text { Cronbach }(\boldsymbol{A})\end{array}$ & $\begin{array}{c}\text { Nilai } \\
\text { Kesahan item }\end{array}$ & Interpretasi Item \\
\hline Tekanan Kerja & 20 & 0.905 & 0.9 & Sangat baik \\
Keletihan Emosi & 9 & 0.893 & 0.8 & Baik \\
Depersonalisasi & 5 & 0.667 & 0.6 & Boleh Diterima \\
Pencapaian Peribadi & 8 & 0.938 & 0.9 & Sangat Baik \\
\hline
\end{tabular}

\section{Hasil Kajian}

\section{Demografi Responden}

Kajian ini melibatkan seramai 136 responden $(\mathrm{n}=136)$. Jadual 2 menunjukkan analisis kekerapan dan peratusan demografi dalam kajian ini. Seramai 60 orang (45.3 peratus) merupakan responden lelaki manakala 76 orang (54.7) merupakan responden perempuan. Majoriti umur responden adalah dalam lingkungan 26 tahun hingga 30 tahun (35.9 peratus) dan responden yang paling sedikit berumur 41 tahun hingga 45 tahun (14.4 peratus). Seramai 81 orang (58.3 peratus) responden telah berkahwin dan 49 orang (37.1 peratus) responden adalah bujang dan selebihnya seramai 6 orang (4.3 peratus) responden merupakan janda atau duda. Dalam pada itu, guru opsyen pendidikan jasmani mencatatkan bilangan tertinggi iaitu seramai 89 orang (66.2 peratus) responden manakala selebihnya 47 orang (33.8 peratus) adalah guru bukan opsyen pendidikan jasmani. Seramai 50 orang (38.2 peratus) responden mempunyai pengalaman mengajar sekitar 1 tahun hingga 5 tahun dan seramai 9 orang (6.5 peratus) responden mempunyai pengalaman mengajar sekitar 16 tahun hingga 20 tahun merupakan jumlah yang paling rendah.

Jadual 2: Analisis Kekerapan dan Peratusan Demografi

\begin{tabular}{lcc}
\hline Demografi & Kekerapan & Peratusan \\
\hline Jantina & & \\
Lelaki & 60 & 45.3 \\
Perempuan & 76 & 54.7 \\
Jumlah & $\mathbf{1 3 6}$ & $\mathbf{1 0 0}$ \\
\hline
\end{tabular}




\begin{tabular}{lcc}
\hline Umur & & \\
$26-30$ tahun & 47 & 35.9 \\
$31-35$ tahun & 35 & 25.2 \\
$36-40$ tahun & 34 & 24.5 \\
$41-45$ tahun & 20 & 14.4 \\
Jumlah & $\mathbf{1 3 6}$ & $\mathbf{1 0 0}$ \\
\hline Status Perkahwinan & 49 & 37.1 \\
Bujang & 81 & 58.3 \\
Berkahwin & 6 & 4.3 \\
Janda/Duda & 136 & 100 \\
Jumlah & & \\
Opsyen Guru & 89 & 66.2 \\
Opsyen Pendidikan Sukan dan Jasmani & 47 & 33.8 \\
Bukan Opsyen Pendidikan Sukan dan Jasmani & $\mathbf{1 3 6}$ & $\mathbf{1 0 0}$ \\
Jumlah & & \\
Pengalaman mengajar & 50 & 38.2 \\
$1-5$ tahun & 41 & 29.5 \\
- 10 tahun & 24 & 17.3 \\
11 - 5 tahun & 9 & 6.5 \\
Melebihi 20 tahun & 12 & 8.6 \\
Jumlah & $\mathbf{1 3 6}$ & $\mathbf{1 0 0}$ \\
\hline
\end{tabular}

\section{Tahap Tekanan Guru Pendidikan Jasmani}

Jadual 3 menunjukkan analisis kesemua dua puluh item bagi konstruk tekanan guru Pendidikan Jasmani mencatatkan tahap tekanan guru Pendidikan Jasmani berada pada tahap sederhana rendah dengan skor $\min =2.92$ dan sisihan piawai $=0.51$. Hasil kajian menunjukkan dua item yang mempunyai bilangan kekerapan rendah bagi 'Tekanan Tinggi' dan 'Tekanan Sangat Tinggi' adalah pada item B6 berkaitan "Saya pening semasa menyiapkan rancangan mengajar" dengan peratus TT dan TST 21.6 peratus dan item B8 "Saya terpaksa menyiapkan kerja sekolah di rumah" dengan peratus TT dan TST 22.3 peratus. Skor kedua-dua item B6 dan B8 menjelaskan bahawa guru tidak mengalami tekanan yang tinggi apabila guru tidak berasa pening semasa menyiapkan rancangan mengajar dan guru terpaksa menyiapkan kerja sekolah di rumah.

Dalam pada itu, terdapat beberapa item yang mencatatkan nilai peratusan yang tinggi. Nilai peratusan yang tertinggi terdapat pada dua item B4 iaitu "Saya berasa bersalah apabila ramai murid-murid saya tidak lulus ujian yang saya beri" dengan peratus TT dan TST berjumlah 75.5 peratus dan item B13 "Saya tertekan kerana mempunyai jumlah waktu mengajar yang banyak" dengan peratus TT dan TST 75.5 peratus. Item B14 "Saya tertekan kerana tidak dapat menghabiskan sukatan pelajaran" dengan peratus TT dan TST berjumlah 72 peratus juga merupakan salah satu skor item yang mencatatkan nilai peratusan tertinggi. Walau terdapat beberapa item yang mencatatkan nilai peratusan tinggi, skor min keseluruhan bagi tahap tekanan guru masih berada pada tahap sederhana rendah.

Jadual 3: Analisis Tahap Tekanan Guru

\begin{tabular}{clccccc}
\hline \multirow{2}{*}{ No } & \multicolumn{1}{c}{ Item } & \multicolumn{5}{c}{$\begin{array}{c}\text { Kekerapan } \\
\text { (Peratusan) }\end{array}$} \\
\cline { 3 - 7 } & & T & TR & TS & TT & TST \\
\hline B1 & $\begin{array}{l}\text { Saya tertekan dalam mengendalikan } \\
\text { pelajar-pelajar yang bermasalah } \\
\text { disiplin }\end{array}$ & 8 & 34 & 52 & 37 & 5 \\
B2 & Saya tertekan dengan tingkah laku & 8 & 25 & 49 & 43 & 11
\end{tabular}


DOI: https://doi.org/10.47405/mjssh.v6i8.948

pelajar yang kurang sopan dan

biadab

B3 Saya berasa seolah-olah saya akan diancam setelah saya menghukum murid-murid yang melanggar disiplin

B4 Saya berasa bersalah apabila ramai murid-murid saya tidak lulus ujian yang saya beri

B5 Saya tidak dapat tidur apabila ramai murid saya tidak memahami pengajaran saya

B6 Saya pening semasa menyiapkan rancangan mengajar

B7 Saya rasa bahawa tugas-tugas di sekolah menyebabkan saya sentiasa sibuk

B8 Saya terpaksa menyiapkan kerja sekolah di rumah

B9 Saya melakukan kerja-kerja pentadbiran yang bukan di dalam bidang tugas

B10 Saya tertekan apabila dilawati oleh jemaah nazir sekolah

B11 Saya tertekan kerana mempunyai masa rehat yang singkat sahaja

B12 Saya tertekan kerana mempunyai kekurangan masa untuk memberi tumpuan kepada pelajar secara individu

B13 Saya tertekan kerana mempunyai jumlah waktu mengajar yang banyak

B14 Saya tertekan kerana tidak dapat menghabiskan sukatan pelajaran

B15 Saya terpaksa menjadi guru ganti apabila ketidakhadiran guru lain

B16 Peluang kenaikan pangkat yang terhad dalam profesion perguruan

B17 Kerja-kerja saya kurang dihargai oleh pentadbir

B18 Saya tertekan kerana struktur kerjaya guru yang kurang menarik

B19 Saya tidak diberi kebebasan untuk memilih mata pelajaran opsyen

B20 Saya tidak mampu bersuara dalam membuat keputusan

Skor Min

Sisihan Piawai

Tahap
(18.0)

(35.3)

$(30.9)$

$\begin{array}{ccccc}61 & 51 & 20 & 4 & 0 \\ (43.9) & (36.7) & (14.4) & (2.9) & (0.0)\end{array}$

$\begin{array}{lllll}2 & 8 & 21 & 67 & 38\end{array}$

(1.4) (5.8) (15.1) (48.2) (27.3)

$\begin{array}{lllll}6 & 38 & 40 & 35 & 17\end{array}$

$(4.3) \quad(27.3) \quad(28.8) \quad(25.2) \quad(12.2)$

$\begin{array}{ccccc}22 & 54 & 30 & 26 & 4 \\ (15.8) & (38.8) & (21.6) & (18.7) & (2.9) \\ 5 & 26 & 58 & 46 & 1 \\ (3.6) & (18.7) & (41.7) & (33.1) & (0.7)\end{array}$

$\begin{array}{ccccc}15 & 59 & 31 & 31 & 0 \\ (10.8) & (42.4) & (22.3) & (22.3) & (0.0) \\ 5 & 26 & 59 & 42 & 4 \\ (3.6) & (18.7) & (42.4) & (30.2) & (2.9)\end{array}$

$\begin{array}{ccccc}37 & 59 & 29 & 10 & 1 \\ (26.6) & (42.4) & (20.9) & (7.2) & (0.7) \\ 6 & 24 & 48 & 41 & 17 \\ (4.3) & (17.3) & (34.5) & (29.5) & (12.2) \\ 5 & 10 & 27 & 61 & 33 \\ (3.6) & (7.2) & (19.4) & (43.9) & (23.7)\end{array}$

$\begin{array}{ccccc}3 & 5 & 23 & 57 & 48 \\ (2.2) & (3.6) & (16.5) & (41.0) & (34.5) \\ 4 & 14 & 18 & 44 & 56\end{array}$

$\begin{array}{llll}(2.9) & (10.1) \quad(12.9) \quad(31.7) \quad(40.3)\end{array}$

$\begin{array}{lllll}54 & 46 & 28 & 8 & 0\end{array}$

$\begin{array}{lllll}(38.8) & (33.1) & (20.1) & (5.8) & (0.0)\end{array}$

$\begin{array}{lllll}38 & 50 & 42 & 6 & 0\end{array}$

$\begin{array}{lllll}(27.3) & (36.0) & (30.2) & (4.3) \quad(0.0)\end{array}$

$\begin{array}{lllll}21 & 52 & 47 & 16 & 0\end{array}$

$\begin{array}{lllll}(15.1) & (37.4) \quad(33.8) \quad(11.5) \quad(0.0)\end{array}$

$\begin{array}{lllll}40 & 38 & 48 & 10 & 0\end{array}$

$\begin{array}{llll}(28.8) & (27.3) \quad(34.5) \quad(7.2) \quad(0.0)\end{array}$

$\begin{array}{lllll}19 & 34 & 23 & 38 & 22\end{array}$

$\begin{array}{llll}(13.7) \quad(24.5) & (16.5) \quad(27.3) \quad(15.8)\end{array}$

$\begin{array}{lllll}9 & 30 & 33 & 44 & 20\end{array}$

$\begin{array}{lllll}(6.5) & (21.6) & (23.7) & (31.7) \quad(14.4)\end{array}$

2.92

0.51

Sederhana Rendah

Petunjuk: T: Tidak Ada Tekanan, TR: Tekanan Rendah, TS: Tekanan Sederhana, TT: Tekanan Tinggi, TST: Tekanan Sangat Tinggi

\section{Tahap Sub Skala Burnout Guru Pendidikan Jasmani}

Hasil analisis menunjukkan tahap sub skala burnout iaitu keletihan emosi berada pada tahap sederhana rendah dengan $(\min =2.49$ dan $\mathrm{sp}=0.43)$. Jadual 4 menjelaskan bahawa nilai kekerapan item $\mathrm{C} 1$ 
DOI: https://doi.org/10.47405/mjssh.v6i8.948

"Saya rasa lemah emosi akibat kerja saya” dengan jumlah peratus KP dan SB 12.9 peratus manakala item C2 "Saya rasa kehabisan tenaga selepas waktu kerja" dengan jumlah peratus KP dan SB 12.3 peratus. Jumlah ini menunjukkan bahawa, guru tidak mengalami burnout pada sub skala keletihan emosi kerana jumlah peratus untuk guru merasa lemah emosi akibat kerja dan guru kehabisan tenaga selepas waktu kerja berapa pada tahap sederhana rendah.

Jadual 4: Tahap Burnout Guru Berdasarkan Sub Skala Burnout Iaitu Keletihan Emosi

\begin{tabular}{|c|c|c|c|c|c|c|}
\hline \multirow[t]{2}{*}{ No } & \multirow[t]{2}{*}{ Keletihan Emosi } & \multicolumn{5}{|c|}{$\begin{array}{l}\text { Kekerapan } \\
\text { (Peratusan) }\end{array}$} \\
\hline & & TP & JB & KKB & KB & SB \\
\hline \multirow[t]{2}{*}{ C1 } & Saya rasa lemah emosi akibat kerja saya & 28 & 46 & 44 & 16 & 2 \\
\hline & & (20.1) & (33.1) & (31.7) & (11.5) & (1.4) \\
\hline \multirow[t]{2}{*}{$\mathrm{C} 2$} & Saya rasa kehabisan tenaga selepas waktu & 9 & 29 & 81 & 13 & 4 \\
\hline & kerja & $(6.5)$ & (20.9) & $(58.3)$ & $(9.4)$ & $(2.9)$ \\
\hline \multirow[t]{2}{*}{$\mathrm{C3}$} & Saya rasa letih bila bangun pagi dan & 48 & 51 & 31 & 5 & 1 \\
\hline & $\begin{array}{l}\text { terpaksa menghadapi satu hari lagi } \\
\text { bekerja }\end{array}$ & (34.5) & $(36.7)$ & (22.3) & (3.6) & $(2.2)$ \\
\hline \multirow[t]{2}{*}{ C4 } & Bekerja bersama orang lain sepanjang & 1 & 58 & 72 & 5 & 0 \\
\hline & hari memberi ketegangan kepada saya & $(0.7)$ & $(41.7)$ & $(51.8)$ & $(3.6)$ & $(0.0)$ \\
\hline \multirow[t]{2}{*}{ C5 } & Saya keletihan tenaga akibat kerja saya & 5 & 28 & 90 & 12 & 1 \\
\hline & & (3.6) & $(20.1)$ & $(64.7)$ & $(8.6)$ & $(0.7)$ \\
\hline \multirow[t]{2}{*}{ C6 } & Saya rasa kecewa dengan kerja saya & 47 & 49 & 36 & 4 & 0 \\
\hline & & (33.8) & (35.3) & (25.9) & (2.9) & $(0.0)$ \\
\hline \multirow[t]{2}{*}{ C7 } & Saya rasa saya bekerja terlalu kuat & 4 & 41 & 64 & 25 & 2 \\
\hline & & (2.9) & (29.5) & $(46.0)$ & (18.0) & (1.4) \\
\hline \multirow[t]{2}{*}{ C8 } & Bekerja secara langsung dengan orang & 14 & 41 & 71 & 9 & 1 \\
\hline & $\begin{array}{l}\text { lain telah memberi terlalu banyak } \\
\text { tekanan pada diri saya }\end{array}$ & $(10.1)$ & $(29.5)$ & $(51.1)$ & $(6.5)$ & $(0.7)$ \\
\hline \multirow[t]{5}{*}{ C9 } & Saya rasa hampir tidak berdaya lagi & 13 & 71 & 40 & 11 & 1 \\
\hline & & (9.4) & (51.1) & (28.8) & (7.9) & $(0.7)$ \\
\hline & Skor Min & 2.49 & & & & \\
\hline & Sisihan Piawai & 0.43 & & & & \\
\hline & Tahap & endah & & & & \\
\hline
\end{tabular}

Petunjuk:TP: Tidak Pernah, JB: Jarang Berlaku, KKB: Kadang-Kadang Berlaku, KB: Kerap Berlaku, SB: Sentiasa Berlaku

Hasil kajian menunjukkan tahap sub skala burnout iaitu depersionalisasi dengan skor $(\min =3.44, \mathrm{sp}=$ 0.65 ) berada pada tahap sederhana tinggi. Ianya jelas dapat dilihat dalam Jadual 5 menjelaskan bilangan peratus bagi item C12 "Saya khuatir tugas ini menjadikan saya lebih tertekan" dengan jumlah peratus KKB dan KP berjumlah 57.6 peratus. Item C14 "Saya rasa pelajar menyalahkan saya dalam beberapa masalah mereka" dengan jumlah peratus KKB dan KP 30.2 peratus. Ini jelas mengatakan bahawa guru sangat mengambil berat tentang masalah pelajar mereka sehingga menyebabkan mereka tertekan dengan pekerjaan mereka.

Jadual 5: Tahap Burnout Guru Berdasarkan Sub Skala Burnout Iaitu Depersionalisasi

\begin{tabular}{lllcccc}
\hline \multirow{2}{*}{ No } & \multicolumn{1}{c}{ Depersionalisasi } & \multicolumn{5}{c}{$\begin{array}{c}\text { Kekerapan } \\
\text { (Peratusan) }\end{array}$} \\
\cline { 3 - 7 } & \multicolumn{1}{c}{ TP } & JB & KKB & KB & SB \\
\hline C10 & Saya rasa bahawa saya melayan & 73 & 40 & 20 & 2 & 1 \\
& $\begin{array}{l}\text { sesetengah pelajar seolah-olah mereka } \\
\text { tiada perasaan }\end{array}$ & $(52.5)$ & $(28.8)$ & $(14.4)$ & $(1.4)$ & $(0.7)$ \\
C11 & $\begin{array}{l}\text { Semenjak menjawat tugas ini saya } \\
\text { menjadi lebih tidak peduli terhadap }\end{array}$ & 81 & 37 & 16 & 2 & 0 \\
& & $(58.3)$ & $(26.6)$ & $(11.5)$ & $(1.4)$ & $(0.0)$
\end{tabular}


perasaan orang lain

C12 Saya khuatir tugas ini menjadikan saya lebih tertekan

C13 Saya sebenarnya tidak peduli apa yang berlaku pada sesetengah pelajar saya

C14 Saya rasa pelajar menyalahkan saya dalam beberapa masalah mereka Skor Min

\begin{tabular}{ccccc}
13 & 42 & 61 & 19 & 1 \\
$(9.4)$ & $(30.2)$ & $(43.9)$ & $(13.7)$ & $(0.7)$ \\
84 & 27 & 21 & 4 & 0 \\
$(60.4)$ & $(19.4)$ & $(15.1)$ & $(2.9)$ & $(0.0)$ \\
40 & 53 & 36 & 6 & 1 \\
$(28.8)$ & $(38.1)$ & $(25.9)$ & $(4.3)$ & $(0.7)$ \\
\hline 3.44 & & & & \\
0.65 & & & &
\end{tabular}

Sisihan Piawai

Sederhana

Tahap

Tinggi

Petunjuk: TP: Tidak Pernah, JB: Jarang Berlaku, KKB: Kadang-Kadang Berlaku, KB: Kerap Berlaku, SB: Sentiasa Berlaku

Berdasarkan Jadual 6 hasil kajian menunjukkan sub skala burnout iaitu pencapaian peribadi berada pada tahap tingi $(\min =4.07$ dan $\mathrm{sp}=0.51)$ sekali gus merupakan sub skala tertinggi berbanding dengan sub skala keletihan emosi dan depersonalisasi. Item yang mempunyai nilai peratusan tertinggi ialah pada C20 "Saya rasa gembira setelah bertungkus lumus mengajar pelajar saya" dengan jumlah peratus KP dan SB berjumlah 90.7 peratus diikuti dengan item C21 "Saya telah berjaya mencapai banyak perkara yang berfaedah dalam kerja" dengan jumlah peratus KP dan SB 83.4 peratus. Jumlah ini menjelaskan bahawa guru berasa gembira apabila mengajar pelajarnya dengan sehabis mungkin dan mencapai banyak faedah dalam bidang perguruan ini.

Jadual 6: Tahap Burnout Guru Berdasarkan Sub Skala Burnout Iaitu Pencapaian Peribadi

\begin{tabular}{|c|c|c|c|c|c|c|}
\hline \multirow[t]{2}{*}{ No } & \multirow[t]{2}{*}{ Pencapaian Peribadi } & \multicolumn{5}{|c|}{$\begin{array}{l}\text { Kekerapan } \\
\text { (Peratusan) }\end{array}$} \\
\hline & & $\mathbf{T P}$ & JB & KKB & KB & SB \\
\hline C15 & $\begin{array}{l}\text { Saya dapat memahami dengan mudah } \\
\text { perasaan pelajar secara efektif }\end{array}$ & $\begin{array}{c}0 \\
(0.0)\end{array}$ & $\begin{array}{c}10 \\
(7.2)\end{array}$ & $\begin{array}{c}32 \\
(23.0)\end{array}$ & $\begin{array}{c}56 \\
(40.3)\end{array}$ & $\begin{array}{c}38 \\
(27.3)\end{array}$ \\
\hline C16 & $\begin{array}{l}\text { Saya dapat menyelesaikan masalah pelajar } \\
\text { dengan efektif }\end{array}$ & $\begin{array}{c}1 \\
(0.7)\end{array}$ & $\begin{array}{c}6 \\
(4.3)\end{array}$ & $\begin{array}{c}23 \\
(16.5)\end{array}$ & $\begin{array}{c}81 \\
(58.3)\end{array}$ & $\begin{array}{c}25 \\
(18.0)\end{array}$ \\
\hline C17 & $\begin{array}{l}\text { Saya yakin dapat mempengaruhi kehidupan } \\
\text { orang lain melalui kerja saya }\end{array}$ & $\begin{array}{c}1 \\
(0.7)\end{array}$ & $\begin{array}{c}4 \\
(2.9)\end{array}$ & $\begin{array}{c}22 \\
(15.8)\end{array}$ & $\begin{array}{c}81 \\
(58.3)\end{array}$ & $\begin{array}{c}28 \\
(20.1)\end{array}$ \\
\hline C18 & Saya rasa penuh bertenaga & $\begin{array}{c}0 \\
(0.0)\end{array}$ & $\begin{array}{c}3 \\
(2.2)\end{array}$ & $\begin{array}{c}21 \\
(15.1)\end{array}$ & $\begin{array}{c}63 \\
(45.3)\end{array}$ & $\begin{array}{c}49 \\
(35.3)\end{array}$ \\
\hline C19 & $\begin{array}{l}\text { Saya mudah mewujudkan suasana yang } \\
\text { tenang untuk pelajar }\end{array}$ & $\begin{array}{c}1 \\
(0.7)\end{array}$ & $\begin{array}{c}9 \\
(6.5)\end{array}$ & $\begin{array}{c}18 \\
(12.9)\end{array}$ & $\begin{array}{c}66 \\
(47.5)\end{array}$ & $\begin{array}{c}42 \\
(30.2)\end{array}$ \\
\hline $\mathrm{C20}$ & $\begin{array}{l}\text { Saya rasa gembira setelah bertungkus lumus } \\
\text { mengajar pelajar saya }\end{array}$ & $\begin{array}{c}1 \\
(0.7)\end{array}$ & $\begin{array}{c}1 \\
(0.7)\end{array}$ & $\begin{array}{c}8 \\
(5.8)\end{array}$ & $\begin{array}{c}44 \\
(31.7)\end{array}$ & $\begin{array}{c}82 \\
(59.0)\end{array}$ \\
\hline C21 & $\begin{array}{l}\text { Saya telah berjaya mencapai banyak perkara } \\
\text { yang berfaedah dalam kerja }\end{array}$ & $\begin{array}{c}1 \\
(0.7)\end{array}$ & $\begin{array}{c}4 \\
(2.9)\end{array}$ & $\begin{array}{c}15 \\
(10.8)\end{array}$ & $\begin{array}{c}58 \\
(41.7)\end{array}$ & $\begin{array}{c}58 \\
(41.7)\end{array}$ \\
\hline $\mathrm{C22}$ & $\begin{array}{l}\text { Saya amat tenang, apabila berhadapan } \\
\text { dengan masalah emosi yang berkaitan } \\
\text { dengan kerja saya }\end{array}$ & $\begin{array}{c}1 \\
(0.7)\end{array}$ & $\begin{array}{c}9 \\
(6.5)\end{array}$ & $\begin{array}{c}35 \\
(25.2)\end{array}$ & $\begin{array}{c}52 \\
(37.4)\end{array}$ & $\begin{array}{c}39 \\
(28.1)\end{array}$ \\
\hline & Skor Min & 4.07 & & & & \\
\hline & Sisihan Piawai & 0.51 & & & & \\
\hline & Tahap & Tinggi & & & & \\
\hline
\end{tabular}

Petunjuk: TP: Tidak Pernah, JB: Jarang Berlaku, KKB: Kadang-Kadang Berlaku, KB: Kerap Berlaku, SB: Sentiasa Berlaku

\section{Hubungan Tekanan dengan Burnout}

Untuk mendapatkan jawapan mengenai hubungan antara tahap tekanan dengan tahap burnout bagi sub skala keletihan emosi, analisis Korelasi Pearson digunakan. Dapatan Korelasi Pearson menunjukkan 
terdapat hubungan yang signifikan antara tahap tekanan dengan sub skala keletihan emosi dengan nilai $\mathrm{r}=-0.224, \mathrm{p}<0.009$. Dengan ini menunjukkan bahawa $\mathrm{H}_{0}$ ditolak kerana tidak terdapat hubungan antara tahap tekanan dengan sub skala keletihan emosi.

Selain daripada itu, hasil kajian mendapati terdapat hubungan yang signifikan antara tahap tekanan dengan sub skala depersonalisasi nilai $\mathrm{r}=0.412$, $\mathrm{p}<0.00$. Ini menunjukkan bahawa $\mathrm{H}_{0}$ ditolak kerana tidak terdapat hubungan antara tahap tekanan dengan sub skala depersonalisasi.

Seterusnya, tidak terdapat hubungan signifikan yang lemah antara tahap tekanan dengan sub skala pencapaian peribadi nilai $r=0.250, p>0.122$. Maka, $\mathrm{H}_{0}$ ditolak kerana tidak terdapat hubungan yang antara tahap tekanan dengan skala pencapaian peribadi.

Jadual 7: Keputusan Korelasi antara Tahap Tekanan dengan Sub Skala Burnout

\begin{tabular}{lcc}
\hline \multicolumn{1}{c}{ Hubungan } & r & Tahap Signifikan Tekanan \\
\hline Keletihan Emosi & -0.224 & 0.009 \\
Depersonalisasi & 0.412 & 0.00 \\
Pencapaian Peribadi & 0.250 & 0.122 \\
\hline
\end{tabular}

\section{Perbincangan Kajian}

Ironinya, kajian ini berkaitan dengan tahap tekanan kerja dan tahap burnout guru-guru Pendidikan Jasmani di Daerah Kota Kinabalu serta mengkaji hubungan tekanan kerja dengan burnout. Dalam pada itu, kajian ini dijalankan bagi melihat hubungan antara tekanan dengan burnout guru Pendidikan Jasmani. Hasil keseluruhan kajian mendapati rata-rata guru-guru Pendidikan Jasmani di Daerah Kota Kinabalu tidak mengalami tekanan yang tinggi kerana hasil dapatan menunjukkan bahawa, tahap tekanan kerja guru berada pada tahap sederhana rendah. Kajian yang dijalankan oleh Lia (2018) turut menjelaskan bahawa tahap tekanan kerja guru sekolah menengah di daerah Pasir Gudang berada pada tahap sederhana rendah. Tahap tekanan kerja bagi ketiga-tiga aspek iaitu kerenah pelajar, beban tugas, dan penghargaan berada pada tahap sederhana rendah manakala aspek kekangan masa berada pada tahap sederhana tinggi. Namun begitu, kajian ini bercanggah dengan kajian Shkëmbi (2015) menjelaskan, kerenah pelajar merupakan penyebab utama berlakunya tekanan guru di tempat kerja serta permasalahan lain seperti tidak mendapat dorongan pihak organisasi, hubungan antara ibu bapa dan penjaga pelajar serta kecekapan peribadi serta profesional yang rendah. Kajian ini bercanggah kerana guru Pendidikan Jasmani di Daerah Kota Kinabalu dapat mengawal kerenah pelajar-pelajarnya walaupun mengajar secara atas talian. Seterusnya, kerenah pelajar merupakan tahap kedua tinggi dalam dapatan kajian ini. Tidak dapat dinafikan bahawa kerenah pelajar ini sukar untuk dikawal kerana para pelajar datang dari pelbagai jenis latar belakang (Hariyati, 2013). Aspek beban tugas dan penghargaan menunjukkan tahap tekanan kerja yang sederhana tinggi dan skor min kedua aspek tidak banyak perbezaan. Dapatan skor ini menjelaskan bahawa pihak pentadbir sekolah tidak membebankan tugas guru dengan pekerjaan perkeranian yang boleh menyebabkan guru terbeban. Selain itu, guru tidak terlalu mengharapkan penghargaan daripada pihak pentadbir ketika melakukan tugas yang diberi.

Seterusnya, tahap burnout guru Pendidikan Jasmani berada pada tahap sederhana rendah bagi sub skala keletihan emosi. Hasil kajian menyokong kajian yang dijalankan oleh Nur (2021) bahawa tahap burnout guru Pendidikan Jasmani di daerah Langkawi berada pada tahap sederhana bagi sub skala keletihan emosi. Punca utama guru mengalami keletihan emosi yang sederhana adalah disebabkan kurangnya tekanan serta beban tugas yang berlebihan sehingga boleh menyebabkan guru mengalami gangguan mental dan fizikal. Selain itu, dapatan kajian bagi tahap burnout sub skala depersonalisasi berada pada tahap sederhana tinggi. Guru mengalami burnout bagi sub skala ini adalah kerana terdapat pelajar yang tidak masuk ke kelas yang dijalankan atas talian. Kajian ini bertentangan dengan kajian Spittle et al. (2015) mengatakan guru-guru Pendidikan Jasmani mengalami depersonalisasi pada tahap rendah. Hal ini disebabkan oleh pandemik Covid-19 yang tengah melanda negara pada masa kini 
menyebabkan pembelajaran dan pengajaran dijalankan atas talian. Oleh itu, pelajar menganggap subjek Pendidikan Jasmani ini tidak penting dan menarik kerana perlu belajar secara atas talian. Tahap pencapaian peribadi Guru Pendidikan Jasmani di Daerah Kota Kinabalu berada pada tahap yang lemah hasil disebabkan kurangnya tekanan kerja yang boleh menyebabkan mereka mencapai peribadi yang baik. Menurut Nur (2021) menjelaskan bahawa, guru melaksanakan tugasnya sebagai seorang pendidik dengan baik agar guru dapat mencapai tahap peribadi yang baik.

Selain daripada itu, hasil dapatan kajian menjelaskan bahawa terdapat hubungan yang signifikan antara tahap tekanan kerja dengan tahap burnout bagi sub skala keletihan emosi dengan depersonalisasi. Kajian lepas mendapati bahawa tingkah laku positif yang rendah dalam kelas sehingga menyebabkan guru menegur dengan kadar teguran yang tinggi dan keras mengakibatkan guru mengalami keletihan emosi. Kekuatan mental dan fizikal guru tidak akan terjejas jika guru berasa selesa dan seronok dengan tugas yang dipimpin. Dalam pada itu, keputusan bagi hubungan tahap tekanan kerja dengan tahap burnout bagi sub skala pencapaian peribadi menunjukkan tidak terdapat hubungan yang signifikan antara tahap tekanan dengan sub skala pencapaian peribadi. Ianya menjelaskan bahawa jika tekanan kerja dapat dibendung dari awal, maka guru boleh menjalankan tugas sebagai seorang pendidik sempurna. Sumber utama tekanan dan burnout di dalam kelas adalah keberkesanan diri yang rendah, atau guru yang kekurangan kepercayaan dalam diri untuk mencapai matlamat mereka (Skaalvik, 2010).

\section{Kesimpulan}

Kesimpulannya, gejala tekanan dan burnout ini tidak boleh dipandang remeh oleh pihak pentadbir sekolah mahupun masyarakat. Ini kerana, jika tekanan dan burnout tidak dibendung dari awal boleh mengganggu kesihatan mental dan fizikal guru dan juga masyarakat sekeliling. Walaupun tahap tekanan kerja guru rendah, ini tidak bermaksud guru tidak mengalami tekanan kerja dalam mendidik pelajar. Selain itu, terdapat hubungan yang signifikan antara tahap tekanan kerja dengan tahap burnout bagi sub skala keletihan emosi dengan depersonalisasi guru Pendidikan Jasmani di Daerah Kota Kinabalu. Sehubungan itu, pihak pengurusan sekolah perlu sentiasa menyokong dan mendorong guru melakukan pekerjaan dengan baik mengelakkan guru berpencen awal. Bagi mengelakkan burnout berlaku, guru perlu segera mengawal tekanan kerja yang dialaminya. Guru perlu sentiasa berfikiran positif ketika menghadapi cabaran dalam mendidik para pelajar bagi mengelakkan guru berasa tertekan dengan kerenah pelajar pada masa kini. Profesion perguruan merupakan satu pekerjaan yang terpenting dan mulia, maka pihak kementerian, sekolah dan guru sendiri perlu mempertingkatkan lagi kualiti kerja sebagai seorang pendidik.

\section{Rujukan}

Azmi Mustafa., . (2005). Tekanan dan kepuasan kerja di kalangan kakitangan Pusat Serenti. Latihan Ilmiah yang tidak diterbitkan. Universiti Kebangsaan Malaysia.

Birhanu, M. G. (2018). Workload determines workplace stress among health professionals working in Felege-Hiwot Referral Hospital, Bahir Dar, Northwest Ethiopia. Journal of Environmental and Public Health, 1-8.

Bottiani, J. (2020). Teacher Stress And Burnout In Urban Middle School. Google Scholars.

Boyle, J.G., Borg,M.G., Falzon, J. M., Baglioni, A. J,. (1995). A structural model of the dimensions of teacher stress. . British Journal of Education Psychology, 65, 49-67.

Choi, B. (2018). Job strain, long work hours, and suicidal ideation in US workers: a longitudinal study. International Archives of Occupational and Environmental Health, 91(7), 865-875. .

Chua, Y. P. (2011). Kaedah Penyelidikan. Selangor: McGraw Hill (Malaysia) Sdn. Bhd.

Collie, R. J. (2012). School climate and social-emotional learning: Predicting teacher stress, job satisfaction, and teaching efficacy. Journal Of Educational Psychology, 104(4), 1189-1204.

Dameria Noviana Habeahan, G. Y. (2020). Beban Kerja, Stres Kerja Dan Kelelahan Kerja Pada Karyawan. Prosiding Pertemuan Ilmiah Nasional Penelitian \& Pengabdian Masyarakat II, , (p. (p. 185).). 
DR ZAFIR KHAN MOHAMED MAKHBUL, . (2019). Warga pendidik yang sinonim stres. Sinar Harian. https://www.sinarharian.com.my/article/48044/KOLUMNIS/Warga-pendidik-yangsinonim-stres. (2021). 'Burnout' bukan perkara remeh. https://www.hmetro.com.my/WM/2021/02/673440/burnout-bukan-perkara-remeh.

Fauziah, N., Rahmah, M. R., Rohani, G., \& Rasimah, A. (2008). Teacher Professional And Organisational Commitment: Evidence From Malaysia. TLC Conference Proceeding. Rothenburg: Germany: EABR.

Fun, W. S. (2010). Faktor-Faktor Yang Mendorong Tekanan Kerja (Stres) Di Kalangan Guru-Guru SJK(C): Satu Kajian Di Tiga Buah Sekolah Di Wilayah Persekutuan. Sematic Scholar.

Grayson, J. L., dan Alvarez, H. K. (2008). School climate factors relating to teacher burnout: A mediator model. Teaching and Teacher Education, 24,1349-1363.

Hakanen, J. J. (2006). Burnout and work engagement among teachers. . J. Sch. Psychol., 43, 495-513. doi: 10.1016/j.jsp.2005.11.001.

Harian, B. (2018). 4.4 peratus suru stres. https://www.bharian.com.my/berita/nasional/2018/08/467001/44-peratus-guru-stres.

Harian, B. (2018). Perubahan sistem pendidikan usah membebankan lagi. https://www.bharian.com.my/rencana/muka10/2018/11/493517/perubahan-sistem-pendidikanusah-membebankan-lagi.

Hariyati Ariffin. (25 Januari 2019). Cabaran menjadi pendidik sejati, disayangi. https://www.bharian.com.my/rencana/komentar/2019/01/523823/cabaran-menjadi-pendidiksejati-disayangi.

Hoy, W. K. (2005). Educational administration: Theory, research and practice. . 7th edition. New York: McGraw-Hill.

Jay Verkuilen, Renzo Bianchi, Irvin Sam Schonfeld, Eric Laurent. (2020). Burnout-Depression Overlap: Exploratory Structural Equation Modeling Bifactor Analysis and Network Analysis. SAGE Journals. https://journals.sagepub.com/doi/abs/10.1177/1073191120911095.

Kamarudin., H. (2013). Faktor Tekanan Kerja Dalam Kalangan Kakitangan MAINS Holdings Sdn.Bhd. . (Tesis Ijazah Sarjana Muda. Open University Malaysia.

Lia Indah Ahmad. (2018). Tekanan Dan Kepuasan Kerja Dalam Kalangan Guru Sekolah Menengah Daerah Pasir Gudang. e-Prosiding Persidangan Antarabangsa Sains Sosial dan Kemanusiaan 2018. Kolej Universiti Islam Antarabangsa Selangor.

Maslach, C. (1996). Maslach burnout inventory manual. https://openlibrary.org/books/OL31425300M/Maslach_burnout_inventory_manual.

Mohamad Zaid, M. A. (2015). Kajian Stres dalam Kalangan Pelajar Wanita Program Sarjana Muda Kejuruteraan di Universiti Tun Hussein Onn Malaysia.

Mohd Effendi@Ewan. (2021). Tinjauan Literatur Bersistematik:Faktor Burnout dalam Kalangan Guru. Malaysian Journal of Sciences and Humanities (MJSSH), 168-186.

Mokhtar b. Ahmad. (1998). Tekanan kerja di kalangan guru sekolah menengah: Satu kajian di Daerah Kulim Bandar Baharu, Kedah Darul Aman. Tesis Sarjana Sains. Bintulu: Universiti Malaysia Sarawak.

Nabilah. (2018). Instrumen Kajian. https://www.scribd.com/document/372489209/INSTRUMENKAJIAN.

Nur Hamizah Binti Zainudin,Tajul Arifin Bin Muhamad,. (2021). Kepuasan Kerja dan Burnout Guru Pendidikan Jasmani di Daerah Langkawi. Malaysian Journal of Social Sciences and Humanities (MJSSH), 6(5), 22 - 34.

Nur Izzaty Mohamad, Azman Ismail , Mohamad Shahril Azwan Mohamad Rozi , Sholihien Ahmad. (2015). Tekanan kerja dan perkaitannya dengan kesihatan pekerja: Kajian empirikal sebuah kontinjen polis di Semenanjung Malaysia. GEOGRAFIA OnlineTM Malaysian Journal of Society and Space 11(10), $63-75$.

Shkembi, F. (2015). Workplace Stress Among Teachers in Kosovo. SAGE JOURNAL. https://journals.sagepub.com/doi/full/10.1177/2158244015614610.

Sidek Mohd Noah \& Jamaludin Ahmad. (2005). Pembinaan Modul: Bagaimana Membina Modul Latihan dan Modul Akademik. Serdang: Penerbit Universiti Putra Malaysia.

Skaalvik, E. a. (2010). Teacher self-efficacy and teacher burnout: A study of relations. Teaching and Teacher Education,. 1059-1069. 

DOI: https://doi.org/10.47405/mjssh.v6i8.948

Smith, M. S. (2020). Burnout prevention and treatment. https://www.helpguide.org/articles/stress/burnout-preventionandrecovery.htm\#: : text $=$ Burnout\%20is\%20a\%20state\%20of,unable\%20to\%20meet\%20constan $t \% 2$.

Spittle, M. K. (2015). Burnout in Secondary School Physical Education. Facta Universitatis - Physical Education and Sport, 13, 33-43.

Teja, S. (2016). Kaedah Persampelan. https://www.slideshare.net/tejasyahremie/kaedah-penyelidikanpersampelan.

Vickovic, S. \&. (2019). Examining the influence of work-family conflict on job stress, job satisfaction and organizational commitment among correctional officers. . 1-21: Criminal Justice Review,.

Waterford. (2019). Teacher burnout: What it is, why it happens, and how you can prevent endof-year burnout. . https://www.waterford.org/education /how-to-prevent-teacher-burnout/.

Zhang, L., Zhao, J., Zheng, H., Xiao, Y., Chen, M., Chen, D., \& Xiao, H. (2014). Mental health and burnout in primary and secondary school teachers in the remote mountain areas of Guangdong Province in the People's Republic of China. Neuropsychiatric Disease and Treatment (pp. 10, 123. ). https://www.dovepress.com/mental-health-and-burnout-in-primary-and-secondary-schoolteachers-in--peer-reviewed-fulltext-article-NDT. 